\title{
PENGARUH GAYA KEPEMIMPINAN, KEBIJAKAN DESENTRALISASI, DAN DISIPLIN KERJA, TERHADAP KINERJA MANAJERIAL PADA SKPD DI KABUPATEN LOMBOK TIMUR TAHUN 2018
}

\author{
H. L. Ahmad Mudhani \\ Institut Pemerintahan Dalam Negeri Nusa Tenggara Barat \\ Email : murdhani.md@gmail.com
}

\begin{tabular}{|c|c|}
\hline ARTICLE INFO & ABSTRACT \\
\hline $\begin{array}{l}\text { Keywords : } \\
\text { leadership style, work discipline, } \\
\text { decentralization policy and managerial } \\
\text { performance } \\
\text { How to cite: } \\
\text { Mudhani, H.L. Ahmad (2018). Pengaruh } \\
\text { Gaya Kepemimpinan, Kebijakan } \\
\text { Desentralisasi, Dan Disiplin Kerja, } \\
\text { Terhadap Kinerja Manajerial Pada } \\
\text { SKPD Di Kabupaten Lombok Timur } \\
\text { Tahun 2018. JMM UNRAM, 7(2), } 129 \text { - } \\
\text { 142 } \\
\text { DOI : } \\
\text { 1029303/jmm.v7i2.389 }\end{array}$ & $\begin{array}{l}\text { In this study aims to determine whether there is an } \\
\text { influence between leadership style, work discipline and } \\
\text { decentralization policy on managerial performance in regional } \\
\text { work units (SKPD) in East Lombok. Using the Saturated } \\
\text { Sample method, } 30 \text { SKPD were taken. The analysis technique } \\
\text { used is multiple linear regression, performs the classic } \\
\text { assumption test (prerequisite) which includes normality test, } \\
\text { autocorrelation test, heteroscedasticity test and } \\
\text { multicollinearity test. After that also hypothesis testing using } \\
\text { t-statistics to test the partial regression coefficient, and F- } \\
\text { statistics to test the effect together with the level of 5\% (0.05). } \\
\text { Based on normality test, autocorrelation test, } \\
\text { multicollinearity test and heteroscedasticity test, all } \\
\text { independent variables are free from disturbances and no } \\
\text { variables deviate from the classical assumptions (Prerequisites). } \\
\text { This shows that the available data fulfills the requirements to } \\
\text { use multiple linear regression equation models. From the } \\
\text { results of the analysis show that leadership style has a positive } \\
\text { effect on managerial performance, decentralization policy has } \\
\text { no effect on managerial performance, and work discipline has a } \\
\text { positive effect on managerial performance. } \\
\text { Pada penelitian ini bertujuan untuk mengetahui } \\
\text { apakah ada pengaruh antara gaya kepemimpinan, } \\
\text { disiplin kerja dan kebijakan desentralisasi Terhadap } \\
\text { kinerja manajerial pada satuan kerja perangkat daerah } \\
\text { (SKPD) di kabupaten lombok timur. Dengan } \\
\text { menggunakan metode Sampel Jenuh, diambil sampel } \\
\text { sebanyak } 30 \text { SKPD. Teknik analisis yang digunakan } \\
\text { adalah regresi linier berganda, melakukan uji asumsi } \\
\text { klasik (prasyarat) yang meliputi uji normlitas, uji }\end{array}$ \\
\hline
\end{tabular}




\section{Jurnal Magister Manajemen Unram \\ Vol. 7, No 2. Juni 2018 NATIONALLY ACCREDITED J OURNAL - DECREE NO. 21/E/KPT/2018}

autokorelasi., uji heteroskedastisitas dan uji mult ikolinearitas. Setelah itu juga uji hipotesis menggunakan t- statistik untuk menguji koefisien regresi parsial, serta F-statistik untuk menguji pengaruh secara bersama-sama dengan level 5\% (0.05).

Berdasarkan uji normalitas, uji autokorelasi, uji multikolinearitas dan uji heteroskedastisita, semua variabel independen terbebas dari gangguan dan tidak ditemukan variabel yang menyimpang dari asumsi klasik (Prasyarat). Hal ini menunjukkan bahwa data yang tersedia telah memenuhi syarat untuk menggunakan model persamaan regresi linier berganda. Dari hasil analisis menunjukkan bahwa gaya kepemimpinan berpengaruh positif terhadap kinerja manajerial, kebijakan desentralisasi tidak berpengaruh terhadap kinerja manajerial, dan disiplin kerja berpengaruh positif terhadap kinerja manajerial.

Copyright (C) 2018 JMM UNRAM. All rights reserved.

\section{PENDAHULUAN}

Proses perencanaan pembangunan daerah perlu diimbangi dengan ketersediaan beberapa hal seperti kapasitas aparatur pemerintah, sumber daya, baik sumber daya manusia maupun sumber daya finansial. Sumber daya manusia memegang peranan yang menentukan dalam keberhasilan pelaksanaan operasi suatu organ-isasi. Hal ini dikarenakan manusia, tidak seperti sumber daya lainnya, memiliki potensi yang berasal dari kapasitas pikirannya, perasaannya, serta kebutuhan dan harapan-harapannya. Manusia juga bisa menjadi pelaksana kebijakankebijakan organisasi. Dengan pertimbangan seperti itu, sumber daya manusia memerlukan perhatian tersendiri dari pihak organisasi karena faktor-faktor seperti kompetensi, dedikasi, dan loyalitas manusia tentu akan berpengaruh terhadap kinerja organisasi (Hasibuan, 2007 dalam Rante, 2014).

Tanpa mengenyampingkan kinerja operasional suatu organisasi, keberhasilan suatu organisasi dalam mencapai tujuannya sebagian besar tergantung pada kinerja manajerialnya. Kinerja manajerial dapat dijelaskan sebagai eksistensi kerja manajer (pimpinan) dalam menyelesaikan pekerjaan dengan seefektif mungkin (Soobaroyen dan Poorundersing 2008 dalam Rante, 2014). Evaluasi atas kinerja yang dilakukan oleh manajer beragam, tergantung pada budaya yang dikembangkan oleh masing-masing organisasi.

Pemerintah dalam melaksanakan tugas dan tanggung jawabnya dituntut untuk menghasilkan kinerja yang baik. Kinerja pemerintah merupakan suatu hal yang penting, karena pemerintah merupakan aktor-aktor yang memiliki pengaruh besar terhadap kepentingan masyarakat. Baik atau buruknya kinerja pemerintah yang merasakan dampaknya adalah masyarakat, sehingga pemerintah diharapkan selalu meningkatkan kualitas baik kemampuan, keterampilan, kreativitas, keteladanan maupun profesionalisme.

Di Indonesia, kebijakan desentralisasi sesungguhnya sudah dimulai sejak lama, yaitu sejak dikeluarkannya Undang-Undang No. 1 Tahun 1945 tentang pembentukan Komite Nasional Indonesia Pusat. Namun demikian, yang disebut sebagai "big bang" kebijakan 
desentralisasi di Indonesia memang baru dimulai sejak 1 Januari 2001, yang ditandai dengan diberlakukannya Undang-Undang No. 22 Tahun 1999 tentang Pemerintahan Daerah yang kemudian diubah dengan Undang-Undang No. 32 Tahun 2004.

Sejak diberlakukannya kebijakan desentralisasi, pemerintah daerah telah menjadi "pemain utama" dalam pembangunan di daerah, termasuk dalam meningkatkan kesejahteraan masyarakat. Hal ini sebagaimana dinyatakan oleh Hirawan (2007) dalam Tasrin dan Wulandari (2012) bahwa selain untuk memenuhi tujuan demokrasi, hal penting lainnya dari pemberlakukan kebijakan desentralisasi adalah untuk meningkatkan kesejahteraan masyarakat.

Melalui desentralisasi, pemerintah daerah lebih banyak berperan dalam pembangunan karena mereka kini memiliki wewenang dan tanggung jawab untuk melakukan pengembangan masyarakat di wilayah yurisdiksinya. Karena pemerintah lokal dinilai memiliki pengetahuan (knowledge) yang lebih baik tentang kebutuhan (needs) dan preferensi (preferences) warga masyarakatnya, maka proses pembangunan dalam model kebijakan desentralisasi seharusnya menjadi lebih efisien daripada model kebijakan sentralisasi dalam kerangka meningkatkan kesejahteraan masyarakat lokal. Hal ini karena dalam kebijakan desentralisasi, pemerintah daerah dapat mengalokasikan sumber daya dengan lebih baik untuk memenuhi kebutuhan masyarakat. Dengan demikian, secara teoritis, sebagaimana disebutkan sebelumnya bahwa model kebijakan desentralisasi seharusnya mampu membawa tingkat kesejahteraan yang lebih baik dibandingkan bila dengan sistem sentralisasi (terpusat).

Salah satu pendekatan kontingensi utama pada kepemimpinan adalah Model Kepemimpinan Situasional dari Paul Hersey dan Kenneth Blanchard yang dikutip dari Wahjono (2010) mengatakan bahwa "Gaya kepemimpinan yang paling efektif bervariasi dengan kesiapan karyawan. Hersey dan Blanchard mendifenisikan kesiapan sebagai keinginan untuk berpretasi, kemauan untuk menerima tanggung jawab, dan kemampuan yang berhubungan dengan tugas, keterampilan dan pengalaman. Sasaran dan pengetahuan dari pengikut merupakan variabel penting dalam menentukan gaya kepemimpinan yang efektif.

Beberapa penelitian telah dilakukan untuk mengetahui keterkaitan antara kepemimpinan dengan kinerja, misalnya yang dilakukan oleh Ogbonna dan Harris (2000) dalam Budiyono (2016). Penelitian ini menemukan bahwa kepemimpinan yang diperankan dengan baik oleh seorang pemimpin mampu memotivasi karyawan untuk bekerja lebih baik. Hal ini bahkan telah membuat karyawan lebih hati-hati berusaha mencapai target yang diharapkan perusahaan sehingga berdampak positif pada kinerjanya. Yousef (2000) dalam Rante (2014) menyimpulkan bahwa kepemimpinan partisipatif atau konsultatif berdampak pada sikap karyawan yang lebih merasa terikat dengan organisasinya, lebih puas dengan pekerjaan mereka, dan mempunyai kinerja yang lebih tinggi. Elenkov (2002) menunjukan bahwa kepemimpinan secara langsung dan positif berpengaruh terhadap kinerja. Sementara itu, Rowold (2011) dalam Rante (2014) menyimpulkan bahwa kepemimpinan berdasarkan struktur berpengaruh signifikan terhadap kinerja. Lebih lanjut, McMurray et al. (2012) meneliti tentang dampak kepemimpinan terhadap iklim kerja dan ki-nerja organisasi non profit. Hasil penelitiannya menunjukkan adanya pengaruh signifikan kepemimpinan terhadap kinerja.

Penelitian yang dilakukan oleh Ogbonna dan Harris (2000) dalam Budiyono (2016), Yousef (2000) dalam Rante (2014), Elenkov (2002), Rowold (2011) dalam Rante (2014), dan McMurray et al. (2012) menunjukkan bahwa adanya keterkaitan antara kepemimpinan dengan kinerja. Hasil yang berbeda ditunjukan oleh penelitian yang dilakukan Suryo (2010) di Panti Asuhan di Kota Tomohon dan Kabupaten Minahasa. Penelitian ini menemukan bahwa gaya 
kepemimpinan transformasional tidak memiliki pengaruh yang signifikan terhadap kinerja pengelola organisasi. Begitu juga, penelitian yang dilakukan Nurwati et al. (2012). Dalam studi ini ditemukan bukti bahwa kepemimpinan secara umum tidak memiliki pengaruh terhadap kinerja dan perilaku kerja pegawai negeri sipil yang berada pada 33 Satuan Kerja Perangkat Daerah (SKPD) di Propinsi Sulawesi Tenggara.

Penelitian yang dilakukan oleh Rante dkk (2014) menunjukkan bahwa Gaya kepemimpinan berpengaruh terhadap kinerja manajerial. Hal ini menjelaskan bahwa gaya kepemimpinan yang berorientasi pada prestasi mampu meningkatkan kinerja manajerial, di mana kinerja pimpinan SKPD akan meningkat apabila Walikota dapat memotivasi pimpinan SKPD untuk mencapai tujuan organisasi dengan efektif. Desentralisasi berpengaruh terhadap kinerja manajerial. Hal ini menjelaskan bahwa adanya tingkat pendelegasian wewenang dan tanggung jawab dalam pengambilan keputusan mengenai operasi sehari-hari yang diberikan Walikota kepada pimpinan SKPD akan membuat pimpinan SKPD berupaya dalam meningkatkan kinerjanya. Sistem akuntansi manajemen dapat memediasi pengaruh gaya kepemimpinan terhadap kinerja manajerial. Hal ini menjelaskan bahwa kinerja manajerial akan meningkat apabila adanya ketersediaan informasi yang dihasilkan dari sistem akuntansi manajemen, seperti informasi yang disajikan dalam bentuk laporan sesuai dengan model keputusan,yang dibangun oleh gaya kepemimpinan yang diterapkan.

Tujuan dilakukannya penelitian ini adalah untuk memberikan kontribusi kinerja manajerial, gaya kepemimpinan dan desentralisasi pada SKPD di kabupaten lombok timur dan juga untuk menguji dan menemukan bukti empiris pengaruh masing-masing variabel.

\section{LANDASAN TEORI}

Gaya kepemimpinan demokratis adalah kemampuan mempengaruhi orang lain agar bersedia bekerja sama untuk mencapai tujuan yang telah ditetapkan dengan cara berbagai kegiatan yang akan dilakukan ditentukan bersama antara pimpinan dan bawahan. Gaya ini kadang-kadang disebut juga gaya kepemimpinan yang terpusat pada anak buah, kepemimpinan dengan kesederajatan, kepemimpinan konsultatif atau partisipatif. Pemimpin kerkonsultasi dengan anak buah untuk merumuskan tindakan keputusan bersama. Adapun ciri-cirinya sebagai berikut: a.Wewenang pemimpin tidak mutlak; b.Pimpinan bersedia melimpahkan sebagian wewenang kepada bawahan; c. Keputusan dan kebijakan dibuat bersama antara pimpinan dan bawahan; d.Komunikasi berlangsung secara timbal balik, baik yang terjadi antara pimpinan dan bawahan maupun sesama bawahan; e.Pengawasan terhadap sikap, tingkah laku, perbuatan atau kegiatan para bawahan dilakukan secara wajar; f. Prakarsa dapat datang dari pimpinan maupun bawahan; g. Banyak kesempatan bagi bawahan untuk menyampaikan saran, pertimbangan atau pendapat; Tugas-tugas kepada bawahan diberikan dengan lebih bersifat permintaan dari pada intruksi; h. Pimpinan memperhatikan dalam bersikap dan bertindak, adanya saling percaya, saling menghormati.

Disiplin kerja pegawai negeri mutlak harus dijalankan dan ditegakkan demi tumbuh berkembangnya suatu aparatur pemerintah dalam mengamalkan tugas dan tangung jawab yang telah dipercayakan bangsa dan Negara kepada pegawai negeri oleh karena itu sudah menjadi kewajiban setiap pegawai untuk menegakkan disiplin.

Adapun dalam Undang-undang nomor 43 Tahun 1949 tentang perubahan atas Undang-undang nomor 8 Tahun 1974 tentang pokok-pokok kepegawaian bahwa "peraturan disiplin adalah suatu peraturan yang membuat keharusan, larangan dan sanksi, apabila 
keharusan tidak dituruti atau larangan dilanggar. Untuk menjamin tata tertib dan kelancaran pelaksanaan tugas maka dengan tidak mengurangi ketentuan dalam peraturan perundangundangan pidana diadakan disiplin pegawai negeri sipil. Disiplin belum dapat dinyatakan efektif bekerja bilamana penampilan kedisiplinan itu hanya berdasarkan ketakutan. Disiplin dalam arti sejati adalah hasil dari interaksi norma-norma yang harus dipatuhi. Norma-norma itu tidak lain hanya bersangkutan dengan ukuran legalistik melainkan berkaitan dengan etika dan tata krama. Hasibuan (2005:120) berpendapat disiplin adalah kesadaran dan kesediaan seseorang untuk mematuhi semua peraturan organisasi dan norma-norma sosial yang berlaku.

Dengan demikian dapat disimpulkan bahwa disiplin kerja adalah suatu yang kemampuan yang akan berkembang dalam kehidupan kesehariannya seseorang atau kelompok (organisasi) dalam bertaat azas, peraturan, norma-norma, dan perundangundangan untuk melakukan nilai-nilai kaidah tertentu dan tujuan hidup yang ingin dicapai oleh mereka dalam bekerja.

Desentralisasi adalah penyerahan Urusan Pemerintahan oleh Pemerintah Pusat kepada daerah otonom berdasarkan Asas Otonomi. pengertian ini sesuai dengan Undang-undang nomor 23 tahun 2014. Dengan adanya desentralisasi maka muncul otonomi bagi suatu pemerintahan daerah. Desentralisasi sebenarnya adalah istilah dalam keorganisasian yang secara sederhana didefinisikan sebagai penyerahan kewenangan. Dalam kaitannya dengan sistem pemerintahan Indonesia, desentralisasi akhir-akhir ini seringkali dikaitkan dengan sistem pemerintahan karena dengan adanya desentralisasi sekarang menyebabkan perubahan paradigma pemerintahan di Indonesia. Seperti yang telah dijelaskan di atas, bahwa desentralisasi berhubungan dengan otonomi daerah. Sebab, otonomi daerah merupakan kewenangan suatu daerah untuk menyusun, mengatur, dan mengurus daerahnya sendiri tanpa ada campur tangan serta bantuan dari pemerintah pusat. Adanya desentralisasi akan berdampak positif pada pembangunan daerah-daerah tertinggal dalam suatu negara hingga daerah otonom tersebut dapat mandiri dan secara otomatis dapat memajukan pembangunan nasional.

Kinerja manajerial adalah hasil dari proses aktivitas manajerial yang efektif mulai dari proses perencanaan, pelaksanaan, penatausahaan, laporan pertanggungjawaban, pembinaan, dan pengawasan. Variabel kinerja manajerial diukur dengan menggunakan instrumen self rating yang dikembangkan oleh Mahoney dkk (1963), di mana setiap responden diminta untuk mengukur kinerja sendiri ke dalam delapan dimensi, yaitu perencanaan, investigasi, pengkoordinasian, evaluasi, pengawasan, pemilihan staf, negosiasi, dan perwakilan, serta satu dimensi pengukuran kinerja seorang kepala dinas, kepala bagian dan kepala bidang secara keseluruhan. Kinerja manajerial merupakan seberapa jauh manajer melaksanakan fungsifungsi manajemen.

Selanjutnya kinerja manajerial menurut Stoner (1992) dalam Jayanti dan Widodo (2010) adalah seberapa efektif dan efisien manajer telah bekerja untuk mencapai tujuan organisasi. Ada dua alasan menurut Brownel (1982) dalam Wasisto dan Sholihin (2004) mengapa partisipasi menjadi topik yang menarik dalam akuntansi manajemen. Pertama, partisipasi pada umumnya merupakan pendekatan manajerial yang dinilai dapat meningkatkan kinerja anggota organisasi, dan kedua, beberapa penelitian yang menguji hubungan antara partisipasi dengan kinerja menunjukan hasil yang tidak konsisten. 


\section{Jurnal Magister Manajemen Unram \\ Vol. 7, No 2. Juni 2018 \\ NATIONALLY ACCREDITED J OURNAL - DECREE NO. 21/E/KPT/2018}

\section{METODE PENELITIAN}

Jenis penelitian yang dipergunakan dalam penelitian ini adalah ex-post facto. Penelitian ex-post facto merupakan suatu penelitian yang mana variabel bebas telah terjadi atau telah ada sebelumnya dan tidak dapat dimanipulasi ketika pengamatan variabel terikat mulai dilakukan. Sedangkan metode yang dipergunakan adalah metode deskriptif kuantitatif yang artinya penelitian yang berusaha mendeskripsikan suatu gejala peristiwa dan kejadian pada saat sekarang serta mengungkapkan data yang telah berlangsung tanpa memanipulasi variabel lainnya yang tanpa mempengaruhi variabel terikat. Jadi, berdasarkan sifatnya yaitu mencoba mengungkapkan suatu fenomena atau kejadian dengan menggunakan dasar perhitungan (Sukardi, 2003:24).

Dalam penelitian ini, penentuan sampel dilakukan dengan menggunakan metode purvosipe sampling, yaitu metode pemilihan sampel dengan kriteria tertentu populasi di jadikan sampel, (Sugiyono, 2013:152). Untuk sampel penelitian ini satuan kerja perangkat daerah (SKPD) Kabupaten Lombok Timur tahun 2018.

Analisi regresi ganda adalah analisis yang digunakan peneliti untuk menentukan bagaimana keadaan (naik turunnya) variabel dependen (kriterium), bila dua (2) atau lebih variabel independen sebagai faktor predictor dimanipulasi (dinaik turunkan nilainya) Sugiyono (2012:277). Jadi analisis regresi ganda akan dilakukan bila jumlah variabel independennya minimal 2.Bentuk persamaan dapat dirumuskan sebagai berikut :

$$
Y=a+B 1 X_{1}+B 2 X 2+B 3 X 3+e
$$

Dimana :

$\mathrm{Y}=$ Kinerja Manajerial

$\mathrm{A}=$ Konstanta

$\mathrm{X}_{1}=$ Gaya Kepemimpinan

$\mathrm{X}_{2}=$ Kebijakan Desentralisasi

$\mathrm{X}_{3}=$ Disiplin Kerja

$\mathrm{B}=$ Koefisien regresi

$\mathrm{E}=$ Error

Uji $t$ digunakan untuk mengetahui pengaruh masing-masing variabel independen (gaya kerja) dan (kebijakan desentralisasi) terhadap variabel dependen (kinerja manajerial). Pengujian $\mathrm{t}$ dilakukan dengan membandingkan $\mathrm{t}$-hitung dengan $\mathrm{t}$-tabel. Jika t-hitung lebih besar dari t-tabel pada tingkat kepercayaan 95\% atau (p-value < 0,05), maka Ha diterima, yang artinya variabel independen yang diuji secara parsial mempunyai pengaruh terhadap variabel dependen. Perhitungan uji $\mathrm{t}$ dalam penelitian ini digunakan untuk menguji signifikansi dari hubungan-hubungan gaya kepemimpinan, disiplin kerja dan kebijakan Desentralisasi terhadap variabel dependen kinerja manajerial. 


\section{HASIL DAN PEMBAHASAN}

Tabel 1

Descriptive Statistics

\begin{tabular}{|l|r|r|r|r|r|}
\hline & N & Minimum & Maximum & Mean & $\begin{array}{r}\text { Std. } \\
\text { Deviation }\end{array}$ \\
\hline gaya kepemimpinan & 120 & 12 & 24 & 20.17 & 2.680 \\
kebijakan & & & & & \\
desentralisasi & 120 & 12 & 20 & 16.82 & 1.874 \\
disiplin kerja & 120 & 10 & 19 & 16.41 & 1.960 \\
kinerja manajerial & 120 & 12 & 24 & 20.47 & 2.487 \\
Valid N & 120 & & & & \\
(listwise) & & & & & \\
\hline
\end{tabular}

Dari tabel di atas menunjukkan jumlah data yang digunakan dalam penelitian ini sebanyak 120 sampel yang diteliti selama tahun 2018. Berdasarkan hasil perhitungan di atas tampak bahwa nilai gaya kepemimpinan tertinggi sebesar 24 dan nilai nilai gaya kepemimpinan terendah (minimum) sebesar 12. Standar deviasi sebesar 2,680 lebih kecil dibandingkan dengan nilai mean (rata-rata) yaitu sebesar 20,17 berarti simpangan gaya kepemimpinan dapat dikatakan relatif baik.

Kebijakan desentralisasi tertinggi sebesar 20 dan nilai kebijakan desentralisasi terendah sebesar 12 Nilai standar deviasi sebesar 1,874 lebih kecil dibandingkan dengan nilai mean (rata-rata) yaitu sebesar 16,82, sehingga simpangan data pada variabel kebijakan desentralisasi ini dapat dikatakan baik.

Disiplin kerja tertinggi sebesar 19 dan nilai disiplin kerja terendah sebesar 10 Nilai standar deviasi sebesar 1,960 lebih kecil dibandingkan dengan nilai mean (rata-rata) yaitu sebesar 16,41, sehingga simpangan data pada variabel disiplin kerja ini dapat dikatakan relatif baik.

Kinerja manajerial tertinggi sebesar 24 dan nilai kinerja manajerial terendah sebesar 12 Nilai standar deviasi sebesar 2,487 lebih kecil dibandingkan dengan nilai mean (rata-rata) yaitu sebesar 20,41, sehingga simpangan data pada variabel kinerja manajerial ini dapat dikatakan relatif baik.

Uji Validitas dan Uji Reliabilitas Instrumen penelitian (kuesioner) yang baik harus memenuhi persyaratan yaitu valid dan reliabel. Untuk mengetahui validitas dan reliabilitas kuesioner perlu dilakukan pengujian atas kuesioner dengan menggunakan uji validitas dan uji reliabilitas. 
Tabel 2

Uji Validitas

\begin{tabular}{clrcc}
\hline \multirow{2}{*}{ Variabel } & Penyataan & $\begin{array}{c}\mathrm{r} \\
\text { hitung }\end{array}$ & $\begin{array}{c}\mathrm{r} \\
\text { tabel }\end{array}$ & keterangan \\
\hline \multirow{4}{*}{ gaya kepemimpinan } & X1.1 & 0,481 & 0,176 & Valid \\
& X1.2 & 0,738 & 0,176 & Valid \\
& X1.3 & 0,528 & 0,176 & Valid \\
& X1.5 & 0,701 & 0,176 & Valid \\
Kebijakan & X2.1 & 0,633 & 0,176 & Valid \\
Desentralisasi & X2.2 & 0,479 & 0,176 & Valid \\
& X2.3 & 0,678 & 0,176 & Valid \\
& X2.4 & 0,176 & Valid \\
& X3.1 & 0,690 & 0,176 & Valid \\
disiplin kerja & X3.2 & 0,537 & 0,176 & Valid \\
& & & & \\
& X3.3 & 0,552 & 0,176 & Valid \\
& X3.4 & 0,617 & 0,176 & Valid \\
& Y1 & 0,682 & 0,176 & Valid \\
& Y2 & 0,602 & 0,176 & Valid \\
& Y3 & 0,682 & 0,176 & Valid \\
& Y4 & 0,622 & 0,176 & Valid \\
& Y5 & 0,541 & 0,176 & Valid \\
\hline
\end{tabular}

Sumber:data diolah

Berdasarkan Tabel 2 di atas, menunjukkan hasil bahwa pernyataan- pernyataan dari masing-masing variabel memiliki nilai $r$ hitung $>r$ tabel, sehingga semua pernyataan dinyatakan valid atau dapat dikatakan bahwa butir pernyataan dari cerminan setiap variabel dalam penelitian ini keberadaannya pada instrumen penelitian dinyatakan valid. Uji reliabilitas dimaksudkan untuk menunjukkan sejauh mana suatu alat ukur dapat dipercaya atau dapat diandalkan apabila diukur berulang kali dengan objek yang sama. Suatu kuesioner dikatakan reliabel atau handal jika jawaban seseorang terhadap pertanyaan atau pernyataan adalah konsisten meskipun diuji berkali-kali. Jika hasil dari cronbach alpha $>0,176$ maka data tersebut mempunyai keandalan yang tinggi (Ghozali, 2005). Berikut hasil uji reliabilitas dalam penelitian ini : 
Tabel 3

Uji Reliabilitas

\begin{tabular}{ccc}
\hline Variabel & Cronbach's Alpha & Keterangan \\
\hline gaya kepemimpinan & 0,574 & Reliabel \\
kebijakan desentralisasi & 0,42 & Reliabel \\
Disiplin Kerja & 0,413 & Reliabel \\
kinerja manajerial & 0,607 & Reliabel \\
\hline
\end{tabular}

\subsection{Analisis Regresi Linear Berganda}

Metode regresi linear berganda dimaksudkan untuk mengetahui keeratan hubungan yang ada diantara kedua variabel. Metode regresi linear ini juga dapat digunakan untuk peramalan dengan menggunakan data berkala (time series).

Dalam mengetahui hubungan dan pengaruh masing - masing variabel independen dengan variabel dependen digunakan teknik analisis regresi linear berganda.

Tabel 4

Regresi Linear Berganda

Coefficients ${ }^{a}$

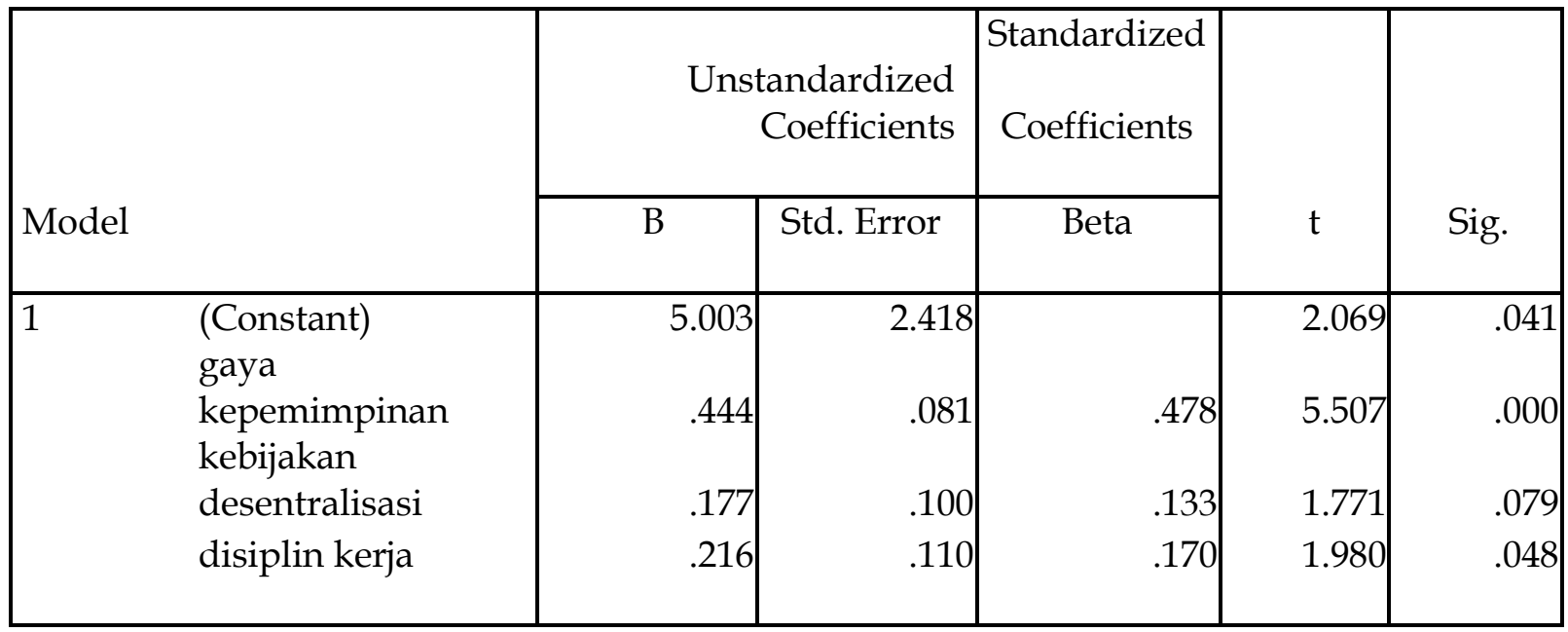

a. Dependent Variable: kinerja manajerial

$\mathrm{Y}=5,003+0,444 \mathrm{X} 1+0,177+0,216$

Persamaan regresi linear berganda dapat interpretasikan sebagai berikut :

1. Konstanta (a) $=5,003$, yang artinya bahwa jika nilai variabel gaya kepemimpinan, kebijakan desentralisasi, dan disiplin kerja dalam keadaan tetap atau tidak mengalami perubahan maka nilai kinerja manajerial adalah sebesar 5,003.

2. $\mathrm{b} 1=0,444$, yang artinya bahwa jika variabel gaya kepemimpinan meningkat satu satuan, maka kinerja manajerila akan meningkat sebesar 0,0,444 dengan asumsi variabel lain tidak mengalami perubahan atau dalam kondisi konstan.

3. $\mathrm{b} 2=0,177$, yang artinya bahwa jika variabel kebijakan desentralisasi meningkat satu satuan, maka kinerja manajerial akan meningkat sebesar 0,177 dengan asumsi variabel lain tidak mengalami perubahan atau dalam kondisi konstan. 
4. $\mathrm{b} 3=0,216$, yang artinya bahwa jika variabel disiplin kerja meningkat satu satuan, maka kinerja manajerial akan meningkat sebesar 0,216 dengan asumsi variabel lain tidak mengalami perubahan atau dalam kondisi konstan.

Tabel 4

Regresi Linear Berganda

Coefficients ${ }^{a}$

\begin{tabular}{|c|c|c|c|c|c|c|}
\hline \multirow{2}{*}{\multicolumn{2}{|c|}{ Model }} & \multicolumn{2}{|c|}{$\begin{array}{r}\text { Unstandardized } \\
\text { Coefficients }\end{array}$} & $\begin{array}{c}\text { Standardized } \\
\text { Coefficients }\end{array}$ & \multirow[b]{2}{*}{$t$} & \multirow[b]{2}{*}{ Sig. } \\
\hline & & B & Std. Error & Beta & & \\
\hline \multirow[t]{4}{*}{1} & (Constant) & 5.003 & 2.418 & & 2.069 & .041 \\
\hline & gaya kepemimpinan & .444 & .081 & .478 & 5.507 & .000 \\
\hline & desentralisasi & .177 & .100 & .133 & 1.771 & .079 \\
\hline & disiplin kerja & .216 & .110 & .170 & 1.980 & .048 \\
\hline
\end{tabular}

a. Dependent Variable: kinerja manajerial

$\mathrm{Y}=5,003+0,444 X 1+0,177+0,216$

Persamaan regresi linear berganda dapat interpretasikan sebagai berikut :

1. Konstanta (a) $=5,003$, yang artinya bahwa jika nilai variabel gaya kepemimpinan, kebijakan desentralisasi, dan disiplin kerja dalam keadaan tetap atau tidak mengalami perubahan maka nilai kinerja manajerial adalah sebesar 5,003.

2. $\mathrm{b} 1=0,444$, yang artinya bahwa jika variabel gaya kepemimpinan meningkat satu satuan, maka kinerja manajerila akan meningkat sebesar 0,0,444 dengan asumsi variabel lain tidak mengalami perubahan atau dalam kondisi konstan.

3. $\mathrm{b} 2=0,177$, yang artinya bahwa jika variabel kebijakan desentralisasi meningkat satu satuan, maka kinerja manajerial akan meningkat sebesar 0,177 dengan asumsi variabel lain tidak mengalami perubahan atau dalam kondisi konstan.

4. b3 $=0,216$, yang artinya bahwa jika variabel disiplin kerja meningkat satu satuan, maka kinerja manajerial akan meningkat sebesar 0,216 dengan asumsi variabel lain tidak mengalami perubahan atau dalam kondisi konstan. 
Tabel 5

Coefficients ${ }^{a}$

\begin{tabular}{|l|r|r|r|r|r|}
\hline \multirow{2}{*}{ Model } & \multicolumn{2}{|c|}{$\begin{array}{c}\text { Unstandardized } \\
\text { Coefficients }\end{array}$} & $\begin{array}{l}\text { Standardized } \\
\text { Coefficients }\end{array}$ & \multirow{2}{*}{$\mathrm{T}$} & \multirow{2}{*}{ Sig. } \\
\cline { 2 - 5 } & \multicolumn{1}{|c|}{ B } & Std. Error & \multicolumn{1}{c|}{ Beta } & & \\
\hline $1 \quad$ (Constant) & 5.003 & 2.418 & & 2.069 & .041 \\
gaya kepemimpinan & .444 & .081 & .478 & 5.507 & .000 \\
Kebijakan & & & & & \\
Desentralisasi & .177 & .100 & .133 & 1.771 & .079 \\
Disiplin Kerja & .216 & .110 & .170 & 1.985 & .048 \\
\hline
\end{tabular}

a. Dependent Variable : kinerja manajerial

Hasil pengujian secara parsial (Uji t pada tabel 1111 Coefficients a dapat diuraikan sebagai berikut :

1. Nilai t-hitung yang diperoleh variabel gaya kepemimpinan (X1) sebesar 5,507 dan nilai $\mathrm{t}$-tabel yang diperoleh dari $(\mathrm{df}=\mathrm{n}-\mathrm{k}$, sig $=0,05)$ sebesar 1,985 . Oleh karena nilai $\mathrm{t}$ hitung > t-tabel yaitu 5,507 > 1,980 dengan nilai signifikansinya sebesar 0,000<0,05, maka dapat dinyatakan bahwa variabel gaya kepemimpinan (X1) mempunyai pengaruh positif dan signifikan terhadap variabel kinerja manajerial (Y). Dengan demikian, maka hipotesis pertama dalam penelitian ini diterima.

2. Nilai t-hitung yang diperoleh variabel kebijakan desentralisasi (X2) sebesar 1,771 dan nilai t-tabel yaitu sebesar 1,980. Oleh karena nilai t-hitung < t-tabel yaitu 1,771 < 1,980 dengan nilai signifikansinya sebesar $0,079>0,05$, maka dapat dinyatakan bahwa variabel kebijakan desentralisasi (X2) tidak mempunyai pengaruh positif dan signifikan terhadap variabel kinerja manajerial $(Y)$. Dengan demikian,maka hipotesis kedua dalam penelitian ini ditolak.

3. Nilai t-hitung yang diperoleh variabel disiplin kerja (X3) sebesar 1,985 dan nilai t-tabel yaitu sebesar 1,980. Oleh karena nilai t-hitung $>\mathrm{t}$-tabel yaitu 1,985 >1,980 dengan nilai signifikansinya sebesar 0,048 < 0,05, maka dapat dinyatakan bahwa variabel kinerja manajerial $(\mathrm{Y})$. Dengan demikian, maka hipotesis ketiga dalam penelitian ini diterima.

Tabel 6

ANOVA $^{b}$

\begin{tabular}{|ll|r|r|r|r|r|}
\hline \multicolumn{1}{|c|}{ Model } & \multicolumn{1}{c|}{$\begin{array}{c}\text { Sum of } \\
\text { Squares }\end{array}$} & Df & Mean Square & F & Sig. \\
\hline $1 \quad$ Regression & 258.081 & 3 & 86.027 & 20.886 & .000 \\
Residual & 477.785 & 116 & 4.119 & & \\
Total & 735.867 & 119 & & & \\
\hline
\end{tabular}

a. Predictors : (Constant), disiplin kerja, kebijakan desentralisasi, gaya kepemimpinan

b. Dependent Variable: kinerja manajerial

Berdasarkan Tabel 6 ANOVAa di atas, maka diperoleh hasil Uji F (Uji Serempak) yang menunjukkan bahwa variabel gaya kepemimpinan, kebijakan desentralisasi, dan disiplin kerja memiliki nilai F-hitung sebesar 20,886 dengan tingkat signifikansi 0,000. Sedangkan nilai F-tabel $(\mathrm{df1}=3$ dan $\mathrm{df} 2=117$, sig. 0,05$)$ maka diperoleh nilai sebesar 2,68. 


\section{Jurnal Magister Manajemen Unram \\ Vol. 7, No 2. Juni 2018 \\ NATIONALLY ACCREDITED J OURNAL - DECREE NO. 21/E/KPT/2018}

Oleh karena nilai F-hitung > Ftabel yaitu 20,886 > 2,68 dengan nilai signifikansi 0,000<0,05, maka dapat dinyatakan bahwa variabel gaya kepemimpinan, kebijakan desentralisasi, dan disiplin kerja secara bersama-sama memiliki pengaruh positif dan signifikan terhadap kinerja manajerial pada satuan kerja perangkat daerah (SKPD) Di Kabupaten Lombok Timur Tahun 2018.

Tabel 7

Model Summary

\begin{tabular}{|l|r|r|r|r|}
\hline Model & \multicolumn{1}{|c|}{$\mathrm{R}$} & R Square & $\begin{array}{c}\text { Adjusted R } \\
\text { Square }\end{array}$ & $\begin{array}{c}\text { Std. Error of } \\
\text { the } \\
\text { Estimate }\end{array}$ \\
\hline 1 & $.592 \mathrm{a}$ & .351 & .334 & 2.029 \\
\hline
\end{tabular}

a. Predictors: (Constant), disiplin kerja, kebijakan desentralisasi, gaya kepemimpinan

Berdasarkan Tabel 7 Model Summaryb di atas, maka dapat dijelaskan bahwa besarnya koefisien korelasi (R) sebesar 0,592 termasuk dalam kategori hubungan yang kuat yang menunjukkan bahwa korelasi antara variabel gaya kepemimpinan, kebijakan desentralisasi, dan disiplin kerja terhadap kinerja manajerial sebesar 59,2\% dan sisanya sebesar $41,8 \%$ dipengaruhi oleh variabel lain yang tidak dimasukkan dalam penelitian ini. Adapun untuk koefisien determinasi $\left(\mathrm{R}^{2}\right)$ sebesar 0,351 yang menunjukkann bahwa besarnya pengaruh variabel kompetensi gaya kepemimpinan, kebijakan desentralisasi, dan disiplin kerja terhadap kinerja manajerial yaitu 35,1\% dan sisanya 65,9\% dipengaruhi oleh variabel lain yang tidak dimasukkan dalam penelitian ini.

Berdasarkan uraian di atas dapat diketahui bahwa dari ketiga variabel independen tersebut, maka variabel gaya kepemimpinan (X1) yang mempunyai pengaruh paling dominan terhadap kinerja manajerial $(\mathrm{Y})$. Hal ini dikarenakan nilai koefisien regresi variabel kompetensi yang paling besar dibanding variabel kebijakan desentralisasi dan variabel disiplin kerja yaitu sebesar 0,444. Oleh karena itu, maka hipotesis ke empat dalam penelitian ini diterima.

\subsection{Pengaruh Gaya Kepemimpinan Terhadap Kinerja Manajerial}

Hasil pengujian menunjukkan bahwa variabel gaya kepemimpinan (X1) mempunyai pengaruh positif dan signifikan terhadap variabel kinerja kinerja manajerial (Y) yang dibuktikan dengan besaran nilai thitung yang diperoleh variabel gaya kepemimpinan (X1) sebesar 5,507 dan nilai $\mathrm{t}$-tabel yang diperoleh dari ( $\mathrm{df}=\mathrm{n}-\mathrm{k}$, sig $=0,05)$ sebesar 1,985 . Oleh karena nilai thitung > t-tabel yaitu 5,507 > 1,980 dengan nilai signifikansinya sebesar 0,000 0,05, dan nilai koefisien regresi (b1) sebesar 0,444. Hal tersebut mengindikasikan adanya hubungan yang searah antara gaya kepemimpinan terhadap kinerja kinerja manajerial, yang artinya jika gaya kepemimpinan diterapkan dengan tepat, maka kinerja manajerial cenderung akan meningkat. 


\section{Jurnal Magister Manajemen Unram \\ Vol. 7, No 2. Juni 2018 \\ NATIONALLY ACCREDITED J OURNAL - DECREE NO. 21/E/KPT/2018}

\subsection{Pengaruh Kebijakan Desentralisasi Terhadap Kinerja Manajerial}

Hasil pengujian menunjukkan bahwa variabel kebijakan desentralisasi (X2) tidak mempunyai pengaruh positif dan signifikan terhadap variabel kinerja kinerja manajerial (Y) yang dibuktikan dengan besaran nilai thitung yang diperoleh variabel kebijakan desentralisasi (X2) sebesar 1,771 dan nilai t-tabel yaitu sebesar 1,980. Oleh karena nilai thitung < t-tabel yaitu $1,771<1,980$ dengan nilai signifikansinya sebesar 0,079>0,05, dan nilai koefisien regresi (b2) sebesar 0,177 . Hal tersebut mengindikasikan tidak ada hubungan yang searah antara kebijakan desentralisasi terhadap kinerja manajerial, yang artinya jika kebijakan desentralisasi diterapkan dengan tepat, maka tidak berdampak pada manajerial cenderung akan meningkat.

\subsection{Pengaruh Disiplin Kerja Terhadap Kinerja Manajerial}

Variabel disiplin kerja(X3) mempunyai pengaruh positif dan signifikan terhadap variabel kinerja manajerial $(\mathrm{Y})$, mempunyai pengaruh positif dan signifikan terhadap variabel kinerja kinerja manajerial (Y) yang dibuktikan dengan besaran nilai thitung yang diperoleh variabel disiplin kerja (X3) sebesar 1,985 dan nilai t-tabel yaitu sebesar 1,980. Oleh karena nilai t-hitung > t-tabel yaitu 1,985 > 1,980 dengan nilai signifikansinya sebesar 0,048< 0,05, dan nilai koefisien regresi (b3) sebesar 0,216. Hal tersebut mengindikasikan adanya hubungan yang searah antara disiplin kerja terhadap kinerja manajerial, yang artinya jika disiplin kerja diterapkan dengan tepat, maka kinerja manajerial cenderung akan meningkat.

\section{KESIMPULAN DAN SARAN}

Berdasarkan analisis yang telah dilakukan pada penelitian ini pada satuan kerja perangkat daerah Kabupaten Lombok Timur pada tahun 2018 menunjukkan bahwa, dari ketiga variabel indevenden yaitu gaya kepemimpinan, kebijakan desentralisasi dan disiplin kerja, memiliki pengaruh masing-masing sebagai berikut :

1. Gaya kepemimpinan (X1) mempunyai pengaruh positif dan signifikan terhadap variabel kinerja kinerja manajerial (Y). Dengan demikian, maka hipotesis pertama dalam penelitian ini diterima.

2. Kebijakan desentralisasi (X2) tidak mempunyai pengaruh positif dan signifikan terhadap variabel kinerja manajerial (Y). Dengan demikian, maka hipotesis kedua dalam penelitian ini ditolak.

3. Disiplin kerja (X3) mempunyai pengaruh positif dan signifikan terhadap variabel kinerja manajerial $(Y)$. Dengan demikian, maka hipotesis ketiga dalam penelitian ini diterima.

Saran yang dapat diberikan pada peneltian ini, bagi satuan kerja perangkat daerah Kabupaten Lombok Timur diharapkan dapat meningkatkan disiplin kerja dan gaya kepemimpinanya dan juga yang paling cendrung adalah kebijakan desentralisasi harus ditingkatkan karena pada penelitian ini kebijakan desentralisasi tidak ada pengarunya terhadap kinerja manajerial. Dan juga bagi peneliti diharapkan tidak hanya meneliti di SKPD lainya juga. 


\section{DAFTAR PUSTAKA}

Budiyono, R., (2016) Pengaruh Tipe Kepemimpinan Terhadap Kinerja Dengan Tekanan Kerja Sebagai Variabel Mediasi, Jurnal STIE Semarang, VOL 8 No. 3 Edisi Oktober 2016

Elenkov, D. S. (2002). "Effects of leadership on organizational performance in Russian companies". Journal of Business Research, Vol. 55, hlm 467- 480.

Ghozali, I. (2005). Aplikasi Analisis Multivariate dengan Program SPSS, Edisi Ketiga. Semarang: Badan Penerbit Universitas Diponegoro.

Jayanti, R. D dan Widodo, H. (2010) Pengaruh Ketidakpastian Lingkungan Dan Karakteristik Informasi Akuntansi Manajemen Terhadap Kinerja Manajerial (Studi Pada Perusahaan BUMN Di Jawa Timur), B I S M A Jurnal Bisnis dan Manajemen, Vol. 2, No. 2, Februari 2010

Mahoney, T. A., T. H. Jerdee, dan S. J. Carroll. (1963). Development of Managing Performance: A Research Approach. South Western. Cincinnati, $\mathrm{OH}$.

McMurray, A.J., I. Md. Mazharul, J.C. Sarros, dan A.P. Merlo. (2012). "The impact of leadership on workgroup climate and performance in a non-profit organization". Leadership dan Organization Development Journal, Vol. 33 No. 6, hlm 522-549.

Nurwati, N.U., S. Margono, dan Surachman. (2012). “Pengaruh Kepemimpinan terhadap Budaya Organisasi, Komitmen Kerja, Perilaku Kerja, Kinerja Pegawai (Studi pada SKPD Provinsi Sulawesi Tenggara)". Jurnal Aplikasi Manajemen, Vol.10, No.1, hlm 111.

Rante, A., Rosidi, dan Djamhuri, A. (2014), Sistem Akuntansi Manajemen, Gaya Kepemimpinan, Dan Desentralisasi Sebagai Determinan Kinerja Manajerial, Jurnal Akuntansi Multiparadigma (JAMAL), Volume 5 Nomor 1, Halaman 1-169, April 2014

Sugiyono. (2013). Metode Penelitian Kuantitatif, Kualitatif dan RED. Bandung: Alfabeta.CV

Sukardi. (2003). Metodologi Penelitian Pendidikan Kompetensi dan Prakteknya, Jakarta: Bumi Aksara.

Suryo, B. D. (2010). Pengaruh Gaya Kepemimpinan Tranformasional, Budaya Organisasi dan Inovasi Terhadap Kinerja (Studi pada Panti Asuhan di Kota Tomohon dan Kabupaten Minahasa). Jurnal Aplikasi Manajemen, Volume 8 Nomor 2, 391-404.

Tasrin, K., dan Wulandari, P. (2012) Kajian Pengaruh Kebijakan Desentralisasi Pada Peningkatan Kesejahteraan Masyarakat (Studi Kasus: Kabupaten/Kota di Provinsi Jawa Barat), Jurnal Borneo Administrator, Volume 8, No. 2, 2012

Wahjono, S. I., (2010) Model Kepemimpinan Situasional Pada Perusahaan Keluarga (kasus UKM di Sentra Industri Wedoro Sidoarjo), Jurnal Bisnis dan Manajemen (BISMA), Jurusan Manajemen Fakultas Ekonomi Universitas Negeri Surabaya, Edisi: Volume 3 No. 1, August 2010 pp. 1-15.

Widodo. (2010). Efek Moderasi Kerja Pada Pengaruh Kompetensi, Reward, Motivasi Terhadap Kinerja. Jurnal Dinamika Manajemen, 1(2), 125-136. 